\title{
Pengembangan buku panduan permainan tradisional untuk meningkatkan kemampuan motorik kasar anak usia 5-6 tahun
}

\author{
Reza Edwin Sulistyaningtyas *, Puji Yanti Fauziah \\ Program Studi Pendidikan Anak Usia Dini, Program Pascasarjana, Universitas Negeri Yogyakarta. \\ Jalan Colombo No. 1, Karangmalang, Yogyakarta, 55281, Indonesia \\ * Corresponding Author. Email: reza.edwin29@gmail.com \\ Received: 5 August 2018; Revised: 10 November 2018; Accepted: 3 December 2018
}

\begin{abstract}
Abstrak
Penelitian ini bertujuan untuk: (1) mengembangkan desain buku panduan permainan tradisional untuk meningkatkan perkembangan motorik kasar anak usia 5-6 tahun dan (2) mengetahui kelayakan dan efektifitas panduan permainan tradisional untuk meningkatkan perkembangan motorik kasar.Jenis penelitian ini adalah penelitian dan pengembangan (Research \& Development). Model pengembangan menggunakan ADDIE yang terdiri dari 5 tahap yaitu: analyze, design, development, implementation dan evaluation. Subjek yang digunakan untuk uji coba produk pada tahap implementasi sebanyak 4 kelas kelompok B (usia 5-6 tahun) yang terdiri dari 66 anak. Teknik pengumpulan data menggunakan pedoman wawancara, angket, observasi dan lembar unjuk kerja. Teknik analisis data menggunakan $t$-test dengan taraf signifikansi 0.05. Permainan tradisional dalam buku panduan diantaranya adalah permainan egrang tempurung/bathok, lompat tali dan engklek. Hasil perhitungan uji $t$-test diperoleh nilai $\alpha=0.000$, nilai tersebut kurang dari 0.05 (<0.05). Kesimpulan yang diperoleh bahwa buku panduan permainan tradisional efektif untuk meningkatkan kemampuan motorik kasar.
\end{abstract}

Kata Kunci: buku panduan, permainan tradisional, kemampuan motorik kasar, anak usia 5-6 tahun

\section{Developing traditional games handbook to improve gross motor ability of 5-6 years-old}

\begin{abstract}
The research aimed to: (1) develop traditional games handbook to improve gross motor ability of 5-6 Years-Old Children, (2) knowing the apropriate by expert and effevtiveness of traditional games handbook to improve gross motor ability of 5-6 years-old. This type of research is research and development $(R \mathcal{E} D)$. The development model which was used in this research was ADDIE model. The model consisted of five steps, that was: analyze, design, develop, implement and evaluate. The subjects used for implementation steps were 4 groups into class B (5-6 years-old children) who were consisting of 66 children. Collecting data used interview guidelines, questionnaire, observation and children performance sheet. Data analysis techniques was t-test with significance level 0.05. The development of traditional games handbook was as egrang tempurung/bathok, lompat tali and engklek. The result of validation by expert and teachers found that the developed products are categorized into a "good" category. The development of traditional games is declared effective in improving the gross motor ability of children.
\end{abstract}

Keywords: handbook, traditional games, gross motor ability, 5-6 years-old children

How to Cite: Sulistyaningtyas, R., \& Fauziah, P. (2019). Pengembangan buku panduan permainan tradisional untuk meningkatkan kemampuan motorik kasar anak usia 5-6 tahun. JPPM (Jurnal Pendidikan dan Pemberdayaan Masyarakat), 6(1), 50-58. doi:https://doi.org/10.21831/jppm.v6i1.23477

doi) https://doi.org/10.21831/jppm.v6i1.23477

\section{PENDAHULUAN}

Anak usia dini merupakan anak yang berada pada usia o-6 tahun yang mengalami pertumbuhan dan perkembangan yang sangat pesat baik dari segi fisik maupun mental. Terbentuknya sel syaraf otak, sebagai modal kecerdasan pada anak telah berkembang 


\section{JPPM (Jurnal Pendidikan dan Pemberdayaan Masyarakat), 6 (1), 2019 - 51 \\ Reza Edwin Sulistyaningtyas, Puji Yanti Fauziah}

sejak bayi. Hal tersebut dibuktikan dalam penelitian oleh ahli neurologi yang menyatakan bahwa pada saat lahir otak bayi mengandung 100 sampai 200 miliar neuron atau sel saraf yang siap melakukan sambungan antarsel (Trianto, 2011, p. 7). Oleh sebab itu usia tersebut disebut dengan usia emas atau golden age. Usia emas atau golden age merupakan fase yang sangat fundamental bagi perkembangan individu karena pada fase inilah terjadi pembentukan dan pengembangan pribadi seseorang (Susanto, 2017, p. 9). Disamping itu anak juga berada pada masa kepekaan yang tinggi atau sensitive period yang tidak akan datang dua kali. Sensitive period merupakan periode dimana anak dapat dengan mudah dan cepat dalam menerima rangsangan yang diberikan. Adanya masa golden age dan sensitive period ini, alangkah baiknya sebagai orang dewasa yang berada dekat dengan anak seperti pendidik, orangtua maupun pengasuh harus memberikan stimulasi yang tepat bagi perkembangan anak. Sangat disayangkan sekali apabila anak yang berusia dini perkembangannya tidak distimulasi dengan baik.

Bermain sangat penting bagi petumbuhan dan perkembangan anak. Kegiatan bermain yang dilakukan anak bukan sebuah paksaan dari orang sekitar. Bermain harus dilakukan atas inisiatif dan keputusan anak itu sendiri sehingga anak merasa senang saat melakukanya. Jika dilakukan dengan perasaan senang maka semua kegiatan bermain akan menghasilkan proses belajar pada anak (Mutiah, 2012, p. 91). Senada dengan pendapat tersebut Dockett dan Fleer (1999, pp. 41-43) menyatakan bahwa bermain merupakan kebutuhan bagi anak, karena melalui bermain anak akan memperoleh pengetahuan yang dapat mengembangkan kemampuan dirinya. Disebutkan juga bahwa bermain merupakan komponen penting dalam kegiatan pembelajaran anak usia dini (Gmitrova, Podhajecká, \& Gmitrov, 2009, p. 339).

Saat ini dunia telah berada pada era perkembangan teknologi yang sangat pesat tidak terkecuali Indonesia. Banyak anak mulai dari balita sudah mengenal gadget, seperti HP, tablet, dan laptop. Berdasarkan hasil survei yang menyatakan bahwa persentase anak berusia 5 tahun ke atas yang pernah mengakses internet dalam 3 bulan terakhir pada tahun 2015 di daerah perkotaan mengalami peningkatan dari $25,84 \%$ menjadi $32.04 \%$, hal tersebut juga terjadi di daerah pedesaan yang mengalami peningkatan dari $8,37 \%$ menjadi $11,70 \%$ (Susenas, 2016). Selain itu hasil penelitian yang dilakukan oleh Mutema (2013, p. 62) menyebutkan bahwa sekitar $80 \%$ dari 50 subjek penelitian menghabiskan waktu untuk menonton TV. Oleh karena itu dari tahun ke tahun persentase anak berusia 5 tahun yang bermain gadget semakin meningkat dan masih banyak anak menghabiskan waktu luang saat di rumah untuk menonton TV.

Penggunaan gadget pada anak memiliki dampak negatif, ketika anak terlalu sering mengoperasikan gadgetakan menimbulkan sakit mata, mata kemerahan dan dapat berakibat penggunaan kacamata. Dampak lainnya seperti anak menjadi ketergantungan akan bermain gadget, sehingga tidak mau bermain bersama teman di luar rumah karena sudah asyik bermain dengan gadget. Bermain gadget merupakan aktivitas pasif karena anak akan lebih sering duduk, sehingga aktivitas geraknya sangat minimum. Pada saat aktivitas gerak, sentuhan dan hubungan pada anak menghilang maka akan terjadi hambatan perkembangan pada anak dan munculnya masalah mengenai perhatian sampai anak berusia 7 tahun (Christakis, Zimmerman, DiGiuseppe, \& McCarty,2004, p. 679; Rowan, 2013, p. 2;). Anak yang kurang melakukan kegiatan motorik akan membuat perkembangan motoriknya menjadi kurang optimal.

Kemampuan motorik kasar merupakan salah satu aspek perkembangan yang sangat penting untuk anak usia dini. Penelitian yang dilakukan oleh Hernandez \& Cacola (2015, p. 574) mengatakan bahwa terdapat hubungan yang signifikan antara perkembangan motorik kasar dengan kognitif. Studi lain menyatakan bahwa ada keterkaitan antara keterampilan motorik kasar dengan kesiapan anak masuk sekolah. Rendahnya kesiapan anak masuk sekolah dilatarbelakangi oleh kurangnya stimulasi yang berkaitan dengan keterampilan motorik kasar sebagai bentuk intervensi untuk menangani masalah tersebut (Sherry \& Draper, 2013, p. 1293). Selain itu hasil penelitian Tepeli (2013, p. 50) 


\section{JPPM (Jurnal Pendidikan dan Pemberdayaan Masyarakat), 6 (1), 2019 - 52 \\ Reza Edwin Sulistyaningtyas, Puji Yanti Fauziah}

menunjukkan bahwa semakin meningkatkan kemampuan motorik kasar maka semakin meningkat pula keterampilan visual persepsi. Oleh karena itu sudah seharusnya pembelajaran di sekolah memberikan waktu yang lebih banyak pada kegiatan bermain yang membutuhkan kemampuan motorik kasar.

Fakta yang ada di lapangan bahwa kemudahan dalam mengaksesteknologi membuat anak lebih mengenal bermain dengan gadget dibandingkan dengan bermain aktif yang membutuhkan kemampuan seluruh anggota badan. Selain itu anak juga lebih mengenal permainan modern yang menggunakan teknologi canggih sehingga jarang bahkan tidak pernah anak-anak bermain permainan tradisional saat di rumah dan di sekolah. Selain itu beradasrkan hasil survey pada 40 guru sebanyak $72.5 \%$ guru memerlukan buku panduan untuk membantu dalam menerapkan permainan tersebut. Padahal melalui permainan tradisional dapat meningkatkan semua aspek perkembangan anak usia dini. Oleh karena itu dalam penelitian ini bertujuan untuk mengembangkan buku panduan permainan tradisional untuk meningkatkan kemampuan motorik kasar anak usia 5-6 tahun. Melalui media buku panduan dapat membantu guru dalam menerapkan permainan tradisional.

\section{METODE}

Penelitian ini menggunakan metode penelitian dan pengembangan model ADDIE (Analyze, Design, Development, Implementation dan Evaluations). Metode penelitian pengembangan merupakan metode penelitian yang menghasilkan suatu produk tertentu dan mengkaji keefektifan dari produk tersebut. Guna mengetahui keefektifan dari produk yang dihasilkan maka digunakan metode eksperimen.

Uji coba pengembangan pada penelitian ini melalui 2 evaluasi yaitu evaluasi formatif dan sumatif. Evaluasi formatif yaitu uji kelayakan pengguna yang dilakukan oleh guru untuk menilai produk yang dikembangkan. Selanjutnya dilakukan implementasi dan evaluasi sumatif dengan menerapkan produk dalam proses pembelajaran. Pelaksanaan implementasi menggunakan metode eksperi- men dengan pendekatan nonequivalent control group design. Prosedur penelitiannya dengan melibatkan 2 kelas yaitu kelas kontrol dan eksperimen.

Pada penelitian ini penentuan subjek uji coba menggunakan purposive sampling. Jenis pengambilan sampel ini didasarkan pada tujuan yang ditetapkan oleh peneliti diantaranya adalah model pembelajaran yang digunakan berbentuk sentra, guru yang memadai dan sarana prasarana yang ada di sekolah. Berdasarkan tujuan tersebut peneliti memilih 2 sekolah yang digunakan dalam penelitian yaitu TK Prima Sanggar dan TK IT Salsabila Al Muthi'in. Implementasi dalam menerapkan buku panduan permainan tradisional sebanyak 66 anak dan 4 guru.

Teknik pengumpulan data dalam penelitian ini menggunakan wawancara, angket dan observasi. Wawancara digunakan untuk mengumpulkan informasi mengenai guru, anak, proses pembelajaran dalam menstimulasi kemampuan motorik kasar dan penerapan permainan tradisional di sekolah dengan menggunakan pedoman wawancara. Angket ditujukan untuk ahli media, ahli materi dan guru. Angket ahli materi untuk memperoleh penilaian validasi dari para ahli terkait penyusunan draft panduan yang dikembangkan secara kelayakan isi, bahasa dan gambar. Angket ahli media untuk memperoleh penilaian meliputi bahasa, tulisan dan gambar. Kemudian angket untuk guru ditujukan untuk memperoleh data mengenai tingkat kelayakan dari draft panduan yang dikembangkan. Teknik pengumpulan data observasi dengan instrumen lembar observasi digunakan untuk mengukur efektifitas penggunaan buku panduan permainan tradisional terhadap kemampuan motorik kasar anak usia 5-6 tahun.

Teknik analisis data dalam penelitian ini menggunakan analisis data deskripsi kuantitatif untuk mengetahui kelayakan buku panduan dan menggunakan SPSS 16 for windows untuk mengetahui efektivitas buku panduan dalam meningkatkan kemampuan motorik kasar anak usia 5-6 tahun. Independent sample t-test digunakan untuk menghitung pretest kelas kontrol \& eksperimen dan posttest kelas kontrol \& eksperimen. Paired sample t-test digunakan untuk meng- 


\section{JPPM (Jurnal Pendidikan dan Pemberdayaan Masyarakat), 6 (1), 2019 - 53 \\ Reza Edwin Sulistyaningtyas, Puji Yanti Fauziah}

hitung pretest \& posttest kelompok kontrol dan pretest \& posttest kelompok eksperimen.

\section{HASIL DAN PEMBAHASAN}

\section{Penelitian Pendahuluan}

Analisis kebutuhan dilakukan dengan menggunakan wawancara, observasi dan angket. Pengumpulan data menggunakan wawancara dilakukan pada 4 guru TK, hal ini bertujuan untuk mengetahui informasi mengenai guru, anak, proses pembelajaran dan penerapan permainan tradisional. Berdasarkan hasil wawancara mengenai penerapan permainan tradisional secara umum guru menjawab bahwa masih jarang dalam menerapkan permainan tradisional. Selanjutnya analisis kebutuhan didukung dengan survey yang menggunakan angket yang disebar ke 40 guru. Hasil yang diperoleh adalah sebanyak $77.5 \%$ guru menyatakan bahwa jarang menerapkan permainan tradisional dan sebanyak $2.5 \%$ guru tidak pernah menerapkan permainan tradisional dalam satu tema. Hal tersebut disebabkan karena berbagai hambatan yang guru temui dalam menerapkan permainan tradisional diantaranya keterbatasan sumber bacaan, kurangnya pemahaman guru, waktu yang terbatas, jumlah guru yang terbatas dan fasilitas yang kurang memadai. Selain itu berdasarkan hasil wawancara bahwa terlalu banyak administrasi yang harus dikerjakan guru seperti mengerjakan laporan harian, mingguan dan bulanan anak sehingga membuat guru memilih kegiatan yang mudah dilakukan seperti menggunakan buku kegiatan anak dan lembaran pengerjaan. Selanjutnya sebanyak $72.5 \%$ guru memerlukan buku panduan untuk dapat membantu menerapkan permainan tradisional di kelas. Sisanya guru memilih gambar dan video sebagai media yang dibutuhkan untuk menerapkan permainan tradisional.

Temuan lain dari hasil observasi bahwa kedua TK khususnya kelas B proses pembelajaran masih didominasi pada kegiatan menulis dan penggunaan LKA. Secara garis besar pembelajaran di TK diawali dengan apersepsi tema yang akan dibahas pada hari itu kemudian guru menjelaskan tugas yang akan dikerjakan selanjutnya anak mengerja- kan tugas yang diberikan guru. Banyak anak yang ingin segera menyelesaikan tugas yang diberikan agar dapat cepat bermain di luar. Pembelajaran yang diterapkan untuk meningkatkan motorik kasar jarang dimasukkan ke dalam proses pembelajaran karena sudah masuk dalam kegiatan mingguan seperti senam. Selain itu sarana dan prasarana yang ada sudah cukup memadai dalam kegiatan pembelajaran, namun belum dapat digunakan secara maksimal.

\section{Penyusunan Prototipe Produk}

Berdasarkan pada hasil analisis maka produk yang akan dikembangkan dalam penelitian ini adalah buku panduan permainan tradisional untuk meningkatkan kemampuan motorik kasar anak. Adapun komponenkomponen yang akan dikembangkan meliputi pendahuluan, landasan teori mengenai bermain dan permainan tradisional, langkahlangkah permainan tradiisonal (lompat tali, engklek, egrang bathok), rencana pelaksanaan pembelajaran harian (RPPH), lembar penilaian dan rubrik penilaian yang dikembangkan.

\section{Pengembangan Produk*}

Selanjutnya dilakukan uji kelayakan produk buku panduan permainan tradisional (http://tiny.cc/permainantradisional) oleh ahli materi dan ahli media. Pada uji kelayakan materi menilai mengenai kelayakan isi, kebahasaan dan penyajian buku panduan permainan tradisional menggunakan angket penilaian. Berdasarkan pada penilaian oleh validasi ahli materi didapatkan skor rata-rata 3.20 dengan kriteria "baik". Selanjutnya untuk indikator kelayakan isi didapatkan rata-rata 3.29 dengan kriteria "sangat baik". Pada indikator kebahasaan didapatkan rata-rata 3 dengan kriteria "baik". Terakhir pada indikator penyajian didapatkan rata-rata 3.25 dengan kriteria "sangat baik".

Uji kelayakan media menilai mengenai kualitas isi dan tujuan, kualitas pembelajaran dan kualitas teknik buku panduan permainan tradisional dengan menggunakan angket penilaian. Berdasarkan penilaian oleh ahli media didapatkan skor rata-rata 3.21 dengan kriteria "baik". Selanjutnya untuk indikator kualitas isi dan tujuan diperoleh rata-rata 


\section{JPPM (Jurnal Pendidikan dan Pemberdayaan Masyarakat), 6 (1), 2019 - 54 \\ Reza Edwin Sulistyaningtyas, Puji Yanti Fauziah}

3.29 dengan kriteria "sangat baik". Pada indikator kualitas pembelajaran didapatkan rata-rata 3.25 dengan kriteria "sangat baik". Terakhir pada indikator kualitas teknik didapatkan rata-rata 3.17 dengan kriteria "baik".

Setelah produk yang dikembangkan dinyatakan layak oleh ahli materi dan media kemudian dilakukan uji kelayakan pengguna oleh guru. Guru yang dilibatkan dalam uji kelayakan pengguna sebanyak 4 guru. Berdasarkan hasil penilaian didapatkan skor ratarata keseluruhan adalah 3.24 dengan kriteria "baik". Selanjutnya untuk indikator kelayakan isi didapatkan rata-rata 3.25 dengan kriteria "sangat baik". Pada indikator penyajian didapatkan rata-rata 3.25 dengan kriteria "sangat baik". Terakhir pada indikator kualitas teknik didapatkan rata-rata 3.22 dengan kriteria "baik", semua dalam kategori baik.

\section{Data Uji Coba Hasil Pengembangan}

Tahap implementasi merupakan tahap mengujicobakan produk yang sudah dinyatakan layak oleh ahli materi, media dan pengguna (guru). Pada tahap uji coba buku panduan permainan tradisional melibatkan 2 sekolah yaitu TK IT Salsabila Al-Muthi'in dan TK Prima Sanggar. Di TK IT Salsabila AlMuthi'in melibatkan 2 guru kelas dan 21 anak kelompok B. Selanjutnya di TK Prima Sanggar melibatkan 3 guru kelas dan 45 anak kelompok B, sehingga diperoleh total subjek penelitian 4 guru kelas dan 66 anak kelompok $B$ yang terbagi menjadi 4 kelas.

Metode yang digunakan dalam mengimplementasi buku panduan permainan tradisional yaitu dengan eksperimen. Jenis eksperimen yang dipilih adalah nonequivalent control group design. Pada jenis eksperimen tersebut memerlukan kelas kontrol dan eksperimen, sehingga pada penelitian ini menggunakan 2 kelas kontrol dan 2 kelas eksperimen. Waktu pelaksanaan implementasi dilakukan 2 bulan, sebelum implementasi produk peneliti mengobservasi keadaan kelas. Observasi dilakukan di TK Prima Sanggar dan TK IT Salsabila Al-Muthi'in untuk mengetahui keadaan awal kelas dan proses pembelajaran yang dilakukan guru dengan menggunakan lembar observasi. Setelah dilakukan observasi langkah selanjutnya adalah mengambil data kemampuan motorik kasar anak sebelum diberi perlakuan atau pre test. Pengambilan data pre test dilakukan pada 2 kelas kontrol dan 2 kelas eksperimen.

Setelah pengambilan data pretest kemudian dilakukan penerapan buku panduan permainan tradisional. Pada penerapan ini dilakukan sebanyak 3 kali pada kelas eksperimen. Pelaksanaan pembelajaran permainan tradisional di TK diawali dengan pemanasan melalui kegiatan berjalan mengelilingi lapangan. Apabila pemanasan telah selesai dilakukan oleh anak-anak langkah berikutnya adalah membagi anak menjadi 3 kelompok. Kelompok dibagi menjadi 3 karena disesuaikan dengan 3 permainan tradisional yang ada di dalam buku panduan diantaranya egrang bathok, lompat tali dan engklek. Selanjutnya dari masing-masing kelompok tesebut memilih satu permainan, jika masingmasing kelompok telah selesai bermain maka pindah ke permainan yang lain secara bergantian. Setelah anak-anak menyelesaikan permainan anak kembali membentuk lingkaran dengan posisi duduk dan kaki diluruskan. Hal ini merupakan tahap pendinginan supaya energi anak kembali ke keadaan normal. Setelah penerapan dilakukan dalam seminggu selanjutnya peneliti mengambil data kemampuan motorik kasar anak setelah perlakuan.

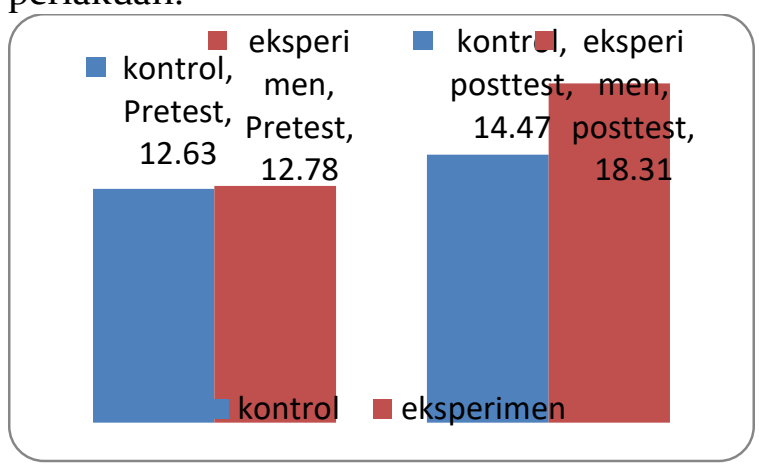

Gambar 1. Hasil pre test dan posttest kemampuan motorik kasar kelas kontrol dan eksperimen

Berdasarkan Gambar 1 dapat diperoleh data mengenai rata-rata kemampuan motorik kasar sebelum perlakuan/pretest pada kelas kontrol sebesar 12.63 dan pretest pada kelas eksperimen sebesar 12.78. Hal ini menunjukkan bahwa pretest kelas kontrol dan kelas eksperimen tidak jauh berbeda. Selanjutnya 


\section{JPPM (Jurnal Pendidikan dan Pemberdayaan Masyarakat), 6 (1), 2019 - 55 \\ Reza Edwin Sulistyaningtyas, Puji Yanti Fauziah}

rata-rata kemampuan motorik kasar setelah perlakukan/posttest pada kelas kontrol sebesar 14.47 dan posttest pada kelas eksperimen sebesar 18.31. Pada kelas eksperimen menunjukkan bahwa adanya peningkatan pada kemampuan motorik kasar terlihat dari rata-rata pretest dan posttest yang berbeda dan mengalami peningkatan.

Berdasarkan data deskriptif statistika mengenai kemampaun motorik kasar, maka didapatkan perbedaan kemampuan motorik kasar yang menerapkan buku panduan permainan tradisional pada kelas eksperimen dengan kemampuan motorik kasar pada kelas kontrol. Meskipun begitu untuk mengetahui seberapa signifikan perbedaan kemampuan motorik kasar di kelas kontrol dan eksperimen maka dilakukan pengujian menggunakan $t$-test.

Uji t-test awal digunakan untuk melihat kemampuan motorik kasar sebelum diberikan perlakuan pada kelas kontrol dan eksperimen. Apabila nilai rata-rata dari pretest kelas kontrol dan eksperimen tidak ada perbedaan/sama maka dapat dikatakan bahwa kelas tersebut baik untuk dijadikan kelas eksperimen dan kontrol.

Tabel 1. Hasil Kemampuan Motorik Kasar Kelompok Kontrol dan Eksperimen

\begin{tabular}{lll}
\hline Kemampuan Motorik & \multicolumn{2}{c}{ Sig. (2-tailed) } \\
\cline { 2 - 3 } Kasar & Pretest & Posttest \\
\hline $\begin{array}{l}\text { kelompok kontrol dan } \\
\text { eksperimen }\end{array}$ & 0.640 & o.ooo \\
\hline
\end{tabular}

Berdasarkan hasil Tabel 1 menunjukkan bahwa pretest kelompok kontrol dan eksperimen sebesar 0.640. Pengambilan keputusan yaitu apabila hasil uji $t$-test lebih besar dari 0.05 (>0.05) maka tidak ada perbedaan ratarata antara kelompok kontrol dan eksperimen, namun apabila uji $t$-test kurang dari $0.05(<0.05)$ maka ada perbedaan rata-rata antara kelompok kontrol dan eksperimen. Hasil yang diperoleh dari uji independent sample t-test pada pretest kelompok kontrol dan eksperimen lebih besar dari 0.05 (>0.05), sehingga dapat disimpulkan bahwa tidak ada perbedaan rata-rata pretest kelompok kontrol dan eksperimen. Selanjutnya kemampuan motorik kasar setelah diberi perlakuan/ posttest pada kelas kontrol dan eksperimen memiliki nilai signifikansi sebesar o.ooo. Maka dapat disimpulkan bahwa ada perbedaan rata-rata posttest kelompok kontrol dan eksperimen.

Setelah menemukan hasil perbedaan pretest kelompok kontrol-eksperimen dan posttest kelompok kontrol-eksperimen selanjutnya mencari perbedaan pretest-posttest kelompok kontrol dan pretest-posttest kelompok eksperimen dengan menggunakan paired sample t-test. Penggunaan uji paired sample t-test dikarenakan populasi yang akan dihitung mendapatkan dua perlakuan. Tabel 2 merupakan hasil uji paired sample t-test pretest dan posttest kelas kontrol dan eksperimen:

Tabel 2. Hasil Kemampuan Motorik Kasar Pretest dan Posttest

\begin{tabular}{lll}
\hline \multicolumn{1}{c}{ Kemampuan } & \multicolumn{2}{c}{ Sig. (2-tailed) } \\
\cline { 2 - 3 } motorik kasar & Kontrol & Eksperimen \\
\hline pretest dan post- & o.0o1 & o.ooo \\
test & & \\
\hline
\end{tabular}

Hasil tabel 2 atas perhitungan uji paired sample t-test menunjukkan nilai signifikansi kemampuan motorik kasar sebelum dan sesudah diberi perlakukan pada kelas kontrol sebesar 0.001. Selanjutnya nilai signifikansi kemampuan motorik kasar sebelum dan sesudah diberi perlakukan pada kelas eksperimen sebesar 0.0oo. Hasil dari kedua uji paired sample $t$-test menunjukkan bahwa nilai signifikansi kurang dari 0.05 (<0.05), maka dapat disimpulkan bahwa terdapat perbedaan peningkatan kemampuan motorik kasar antara kelas kontrol dan eksperimen. Namun hasil dari kemampuan motorik kasar sebelum dan sesudah diberi perlakukan pada kelas eksperimen yang menggunakan permainan tradisional lebih signifikan dibanding dengan kemampuan motorik kasar sebelum dan sesudah diberi perlakukan pada kelas kontrol.

Berdasarkan analisis t-test diperoleh hasil adanya perbedaan kemampuan motorik kasar antara pretest dan posttest. Nilai posttest pada kelas eksperimen lebih tinggi dibanding pretest sehingga dapat disimpulkan terdapat perbedaan antara sebelum dan sesudah menggunakan buku panduan permainan tradisional. Pada kelas kontrol juga 


\section{JPPM (Jurnal Pendidikan dan Pemberdayaan Masyarakat), 6 (1), 2019 - 56 \\ Reza Edwin Sulistyaningtyas, Puji Yanti Fauziah}

terdapat perbedaan antara pretest dan posttest. Namun, hasil uji t-test pada kelas eksperimen lebih signifikan dibanding dengan kelas kontrol. Oleh karena itu dapat disimpulkan bahwa permainan tradisional lebih efektif untuk meningkatkan kemampuan motorik kasar.

\section{Kajian Produk Akhir}

Penelitian ini bertujuan untuk mengembangkan buku panduan permainan tradisional. Buku panduan permainan bertujuan untuk meningkatkan kemampuan motorik kasar anak usia 5-6 tahun. Produk akhir dihasilkan berdasarkan revisi dan masukan yang diberikan oleh ahli dan guru selama proses pengembangan. Berikut merupakan hasil produk akhir masing-masing komponen: Pertama, produk yang dikembangkan adalah buku panduan permainan tradisional untuk meningkatkan kemampuan motorik kasar anak usia 5-6 tahun. Kedua, buku panduan terdiri dari 38 halaman yang terdiri dari pendahuluan, teori bermain dan permainan, permainan tradisional (engklek, egrang tempurung dan lompat tali), rencana pelaksanaan pembelajaran harian dan alat penilaian.

1. Buku panduan berbentuk buku dengan ukuran A4, bagian sampul menggunakan kertas ivory 190 gram dan bagian isi menggunakan kertas HVS 80 gram .

2. Jenis huruf yang digunakan dalam buku panduan adalah Arial dengan ukuran huruf 14.

3. Buku panduan dilengkapi dengan foto sebagai ilustrasi dari setiap tahap permainan.

4. Buku panduan tersebut dapat didownload di http://tiny.cc/permainantradisional

\section{Pembahasan}

Permainan tradisional dapat dikatakan bagian terpenting dari masa kanak-kanak nenek moyang kita dahulu. Permainan tradisional merupakan permainan yang berasal turun-temurun dari suatu daerah. Permainan tradisional memiliki arti penting dan telah meninggalkan pengalaman di masa kecil pada setiap manusia yang memainkannya. Permainan tradisional tidak memerlukan alat peraga mahal dan semua orang bisa memain- kannya, berapapun usia atau jenis kelaminnya (Kovačević \& Opić, 2014, p. 96). Selain itu sebagian besar permainan tradisional dapat menjadi konteks pembelajaran yang berkaitan dengan kehidupan yang dapat terjadi pada anak-anak, permainan tersebut juga memberikan anak sarana untuk belajar tentang budaya (Aypay, 2016, p. 302).

Permainan tradisional memiliki banyak manfaat untuk menstimulasi perkembangan anak usia dini. Hal tersebut didukung oleh hasil penelitian yang menunjukkan bahwa program permainan tradisional sesuai untuk mengembangkan dasar keterampilan motorik (Akbari et.al, 2009, p. 126). Disamping itu terdapat penelitian yang hasilnya menunjukkan bahwa permainan tradisional dapat memainkan peran kunci yang kaitannya dengan aspek emosional dalam pendidikan jasmani (Lavega et.al, 2014, p. 457). Oleh karena itu beragam permainan tradisional dapat menstimulasi perkembangan fisik dan motorik khususnya motorik kasar anak. Salah satu cara untuk membantu guru menerapkan permainan tradisional untuk meningkatkan kemampuan motorik kasar adalah melalui pengembangan buku panduan.

Buku panduan permainan tradisional dikembangkan untuk membantu guru dalam menerapkan kegiatan permainan tradisional. Permainan tradisional merupakan permainan yang dibentuk oleh budaya lokal dan lingkungan setempat dimana permainan tersebut telah ada sejak nenek moyang dan diwariskan dari satu generasi ke generasi berikutnya (Bishop \&Curtis, 2005, p. 33; Mulyani, 2016, pp. 47-48). Guru dapat meningkatkan kemampuan motorik kasar anak melalui penerapan permainan tradisional. Hal tersebut ditunjukkan pada penelitian yang dilakukan oleh Hayati, Myrnawati \& Asmawi (2017, p. 53) yang menyatakan bahwa menerapkan permainan tradisional memiliki pengaruh yang signifikan terhadap kemampuan motorik kasar dibandingkan dengan yang tidak mengajarkan permainan tradisional.

Berdasarkan dari hasil uji efektifitas dalam penelitian ini diperoleh hasil bahwa permainan tradisional lebih efektif untuk meningkatkan kemampuan motorik kasar. Hal tersebut sesuai dengan penelitian terdahulu yang menyatakan bahwa permainan 


\section{JPPM (Jurnal Pendidikan dan Pemberdayaan Masyarakat), 6 (1), 2019 - 57 \\ Reza Edwin Sulistyaningtyas, Puji Yanti Fauziah}

tradisional lebih efektif untuk meningkatkan kemampuan motorik (kontrol objek, lokomotor dan keterampilan dasar). Studi tersebut menemukan bahwa kemampuan motorik kasar dapat dipengaruhi oleh program gerakan yang tepat, salah satunya adalah melalui permainan tradisional (Akbari et.al, 2009, p. 126). Selain itu permainan tradisional merupakan kegiatan yang baru dialami, sehingga anak merasa senang dalam melakukannya. Oleh sebab itu pada saat anak bermain, kemampuan motorik kasar anak meningkat karena memperoleh stimulasi dari kegiatan permainan tradisional yang dilakukan. Hal tersebut sesuai dengan pendapat Mutiah (2012, p. 91) yang menyatakan bahwa jika bermain dilakukan dengan perasaan senang maka semua kegiatan bermain akan menghasilkan proses belajar pada anak. Di samping itu permainan tradisional yang diterapkan dalam penelitian ini dilakukan di luar kelas sehing ga anak dapat berinteraksi langsung dengan lingkungan sekitar. Taheri \& Chahian (2015, p. 221) berpendapat bahwa bermain di udara terbuka dan berinteraksi dengan lingkungan dapat meningkatkan kemampuan fisik-motorik anak.

Buku panduan permainan tradisional yang dikembangkan membantu guru untuk membuat perencanaan pelaksanaan pembelajaran dengan menerapkan permainan tradisional dalam meningkatkan kemampuan motorik kasar. Melalui buku panduan permainan tradisional proses pembelajaran guru untuk meningkatkan kemampuan motorik kasar anak menjadi lebih baik, sehingga kemampuan anak juga akan meningkat lebih baik.

\section{SIMPULAN}

Berdasarkan hasil penelitian dan pengembangan yang dilaksanakan dapat disimpulkan bahwa buku panduan permainan tradisonal dikembangkan untuk pembelajaran motorik kasar yang disesuaikan dengan standar tingkat pencapaian perkembangan anak. Di dalam buku panduan membahas mengenai: (1) pendahuluan; (2) Bermain dan permainan; (3) permainan tradisional; (4) rencana pelaksanaan pembelajaran harian; (5) alat penilaian kegiatan. Melalui buku panduan guru dapat merancang kegiatan pembelajaran yang dapat meningkatkan kemampuan motorik kasar melalui permainan tradisional diantaranya: (1) Engklek, (2) Lompat tali dan (3) Egrang tempurung/bathok.

Buku panduan permainan tradisional untuk meningkatkan kemampuan motorik kasar anak usia 5-6 tahun telah divalidasi oleh ahli dan diuji kelayakan oleh pengguna yaitu guru. Berdasarkan hasil penilaian oleh ahli materi diperoleh hasil bahwa buku panduan permainan tradisional untuk meningkatkan kemampuan motorik kasar anak usia 5-6 tahun dinyatakan layak dengan kategori "baik". Selanjutnya penilaian yang dari ahli media didapatkan hasil dengan kategori "baik". Pada uji kelayakan oleh pengguna diperoleh hasil dengan kategori "baik".

Keefektifan buku panduan permainan tradisional yang dikembangkan setelah di uji coba dengan menggunakan t-test diperoleh hasil bahwa signifikansi pretest dan post test kelompok eksperimen sebesar o.ooo, nilai tersebut kurang dari 0.05 (<0.05). Jadi dapat disimpulkan bahwa terdapat perbedaan antara hasil pretest dan posttest pada kemampuan motorik kasar anak usia 5-6 tahun, sehingga penggunaan buku panduan permainan tradisional dapat dikatakan efektif dalam meningkatkan kemampuan motorik kasar anak usia 5-6 tahun.

\section{DAFTAR PUSTAKA}

Akbari, H., Abdoli, B., Shafizadeh, M., Khalaji, H., Hajihosseini, S., \& Ziaee, V. (2009). The effect of traditional games in fundamental motor skill development in 7-9 year-old boys. Iranian Journal of Pediatrics, 19(2), 123-129.

Aypay, A. (2016). Investigating the role of traditional children's games in teachingten universal values in Turkey. Eurasian Journal of Educational Research, 62, 301-318, http://dx.doi.org/ 10.14689/ejer.2016.62.14

Bishop, J. C., \& Curtis, M. (2005). Permainan anak-anak zaman sekarang di sekolah dasar. Editor: Yovita Hadiwati. Jakarta: PT. Grasindo

Christakis, D.A., Zimmerman, F.J., 
JPPM (Jurnal Pendidikan dan Pemberdayaan Masyarakat), 6 (1), 2019 - 58

Reza Edwin Sulistyaningtyas, Puji Yanti Fauziah

DiGiuseppe, D.L. \& McCarty, C.A. (2004). Early television exposure and subsequent attentional problems in children. Archives of Pediatrics, 679680 .

Dockett, S., \& Fleer, M. (1999). Play and pedagogy in early childhood bending the rules. Australia: Harcourt Brace.

Gmitrova, V., Podhajecká, M., \& Gmitrov, J. (2009). Children's play preferences: implications for the preschool education. Early Child Development and Care, 179(3), 339-351. https://doi.org/10.1080/03004430601101 883

Hayati, Myrnawati \& Asmawi. 2017. Effect of Traditional Games, Learning Motivation and Learning Style on Childhoods Gross Motor Skills. International Journal of Education and Research, 5(7),53-66. Retrieved from http://www.ijern.com/journal/2017/Jul $\mathrm{y}-2017 / 05 . p d f$

Hernandez, A. M., \& Cacola, P. (2015). Motor proficiency predicts cognitive ability in four-year-olds, $23(4), 573-584$.

Kovačević, T., \& Opić, S. (2014). Contribution of traditional games to the quality of students' relations and frequency of students' socialization in primary education. Croation Journal of Education, 16(1), 95-112.

Lavega, P., Alonso, J. I., Etxebeste, J., Lagardera, F., \& March, J. (2014). Relationship between traditional games and the intensity of emotions experienced by participants. Research Quarterly for Exercise and Sport, 85(4), 457-467.

https://doi.org/10.108o/02701367.2014.9 61048

Mulyani, N. (2016). Super asyik permainan tradisional anak Indonesia. Yogyakarta: DIVA Press

Mutema, F. (2013). Shona traditional children's games and songs as a form of indigenous knowledge: An endangered genre. Journal of Humanities and Social Science, 15(3), 59-64.

Mutiah, D. (2012). Psikologi bermain anak usia dini. Jakarta: Penada Media Group.

Rowan, C. (2013). The impact of technology on child sensory and motor development.SensomotorisheIntegratie. Retrieved from http://www.sensomotorischeintegratie.nl/CrisRowan.pdf

Sherry, K., \& Draper, C. E. (2013). The relationship between gross motor skills and school readiness in early childhood: making the case in South Africa. Early Child Development and Care, 183(9), 12931310.https://doi.org/10.1080/03004430.2 012.721358

Survei Sosial Ekonomi Nasional (Susenas). (2016). Persentase penduduk usia 5 tahun ke atas yang pernah mengakses internet dalam 3 bulan terakhir menurut klasifikasi daerah, 2010-2015. Jakarta: Badan Pusat Statistika.

Susanto, A. (2017). Pendidikan anak usia dini: Pengantar dalam berbagai aspeknya. Jakarta: Kencana.

Taheri, L., \& Chahian, G. (2015). Restoration of traditional children's play in Iranian nomadic societies (Case study of Kohgilouyeh and Boyer Ahmad). Children, 2(2), 211-227. https://doi.org/10.3390/children202021 1

Tepeli, K. (2013). The relationship between gross motor skills and visual perception of preschoolers. Turkish Journal of Sport and Exercise, 15 (1), 43-53.

Trianto, T. (2011). Desain pengembangan pembelajaran tematik bagi anak usia dini TK/RA Eanak usia kelas awal $S D / M I$. Jakarta: Kencana. 